\title{
Low-temperature applied to rice seed storage: an efficient protection method against fungal contamination
}

\author{
Temperatura baja aplicada al almacenamiento de semillas de arroz: Eficaz método de \\ protección contra la contaminación por hongos
}

\begin{abstract}
Raimundo Wagner Souza Aguiarr; Deyvid Rocha Brito ${ }^{2}$; Vitor L. Nascimento ${ }^{3}$; Rodrigo Ribeiro Fidelis ${ }^{4}$;
Talita Pereira de Souza Ferreira5; Gil Rodrigues Santos ${ }^{6}$
\end{abstract}

\author{
ARTICLE DATA \\ 1 Professor, PhD, Universidade Federal do Tocantins, \\ Brasil,rwsa@uft.edu.br \\ 2 Research, MSc, Universidade Federal do Tocantins, \\ Brasil,dvbrito06@hotmail.com \\ 3 Research, Ph.D, Universidade Federal do Tocantins, \\ Brasil, vitorlnasc@gmail.com \\ 4 Professor, Ph.D, Universidade Federal do Tocantins, \\ Brasil,fidelisrr@uft.edu.br \\ 5 Professor, Ph.D, Universidade Federal do Tocantins, \\ Brasil, cupufer@gmail.com \\ 6 Professor, Ph.D, Universidade Federal do Tocantins, \\ Brasil, gilrsan@uft.edu.br
}

Cite: Aguiar, R.W.S.; Brito, D.R.; Nascimento, V.L.; Fidelis, R.R.; Ferreira, T.P.S.; Santos, G.R. (2020). Low-temperature applied to rice seed storage: an efficient protection method against fungal contamination. Revista de Ciencias Agrícolas. 37(2): 49-55

doi: https://doi.org/10.22267/rcia.203702.137.

Received: January 172020.

Accepted: December 102020

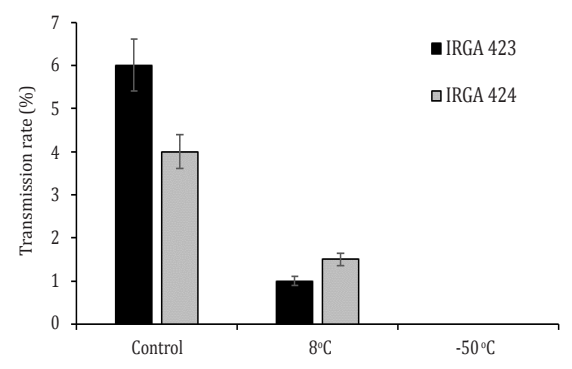

The effect of storage temperatures on fungal seed-to-seedling transmission for rice (Oryza sativa L.) IRGA 423 and 424 seeds after 90-days of storage.
ABSTRACT

Low-temperatures have long been thought to enhance seed health during storage. Here, we tested the effect of low-temperature on the mycoflora associated with rice seeds. Seeds of the IRGA 423 and 424 cultivars were stored in refrigeration $\left(8\right.$ and $\left.-50^{\circ} \mathrm{C}\right)$ or at room temperature $\left(25 \pm 10^{\circ} \mathrm{C}\right)$. Following storage $(1,45$, and 90 days) was investigated the fungi associated with the seeds. We found that low-temperature stored seeds had a lower fungal load than the seeds at room temperature for both cultivars. After 90 days of storage, there is a decrease in its incidence rate average of more than $85 \%$ in the lower temperature $\left(-50^{\circ} \mathrm{C}\right)$. All mycroflora was eliminated at 90 days except for Fusarium sp. The Trichoderma sp. was detected only in IRGA 423 seeds, whereas all other fungi were detected in the treatments in both cultivars. Only Bipolaris sp. was observed in seed-to-seedlings transmission analyses, in both cultivars, at $8^{\circ} \mathrm{C}$, and was not detected at $-50^{\circ} \mathrm{C}$. Based on our results, we recommend low-temperature storage $\left(\right.$ at $\left.-50^{\circ} \mathrm{C}\right)$ of rice seeds.

Keywords: disinfection method; mycoflora phytopathology; refrigeration; seed protection; Oryza sativa L.

\section{RESUMEN}

Las bajas temperaturas han sido pensadas para mejorar la calidad de las semillas durante el almacenamiento desde hace mucho tiempo. Nosotros hicimos un test sobre el efecto que tienen las bajas temperaturas en la micoflora asociada con las semillas de arroz. Las semillas de los cultivos IRGA 423 y 424 se almacenaron en refrigeración $\left(8 \mathrm{y}-50^{\circ} \mathrm{C}\right)$, o en temperatura ambiente $(25$ $\pm 10^{\circ} \mathrm{C}$ ). Con el seguimiento del almacenamiento ( 1,45 y 90 días), se investigó el hongo asociado con las semillas. Encontramos que, para ambos cultivos, las semillas almacenadas a bajas temperaturas presentaron más baja carga de hongos que las almacenadas en temperatura ambiente. Después de 90 días, en almacenamiento a baja temperatura hay una disminución en el promedio de su tasa de incidencia de más del $85 \%\left(-50^{\circ} \mathrm{C}\right)$. Toda la micoflora fue eliminada 
Aguiar et al.- Rice seed storage at low-temperature.

\begin{abstract}
después de 9º días exceptuando por Fusarium sp. La Trichoderma sp. Se detectó únicamente en las semillas del IRGA 423, mientras que todos los demás hongos se detectaron en los tratamientos de ambos cultivos. Sólo se observó Bipolaris sp. en los análisis de transmisión entre semillas en ambos cultivos, a $8^{\circ} \mathrm{C}$, y no se detectó a $-50^{\circ} \mathrm{C}$. Basándonos en nuestros resultados, recomendamos el almacenamiento a baja temperatura $\left(\mathrm{a}-50^{\circ} \mathrm{C}\right)$ de las semillas de arroz.
\end{abstract}

Palabras clave: método de desinfección; fitopatología de la micoflora; refrigeración; protección de semillas; Oryza sativa $L$.

\section{INTRODUCTION}

Rice (Oryza sativa L.) is one of more important commodities of the world with more than 760 Million Tons produced in 2017, highlight Asian countries' production and Brazil, one of the top 10 producers (FAOSTAT, 2019). Once this is a cereal that feeds more than half of the world's population, many efforts have been made to food security of this crop (Godfray et al., 2010). In this sense, fungal contamination is the one of main problems related to seed production and storage; therefore, the elimination or minimization of contamination by mycotoxins and fungi is crucial for reducing economic loss in agriculture (Adeyeye, 2016).

Seed storage is complicated by climatic conditions between regions and the potential reduction of quality. However, treatments as chemical disinfection, heat and/or ionizing radiation have been developed aimed to reduce the number of microorganisms infesting the surface and inner tissue of seeds (Khamsen et al., 2016). In this context, low-temperature emerges as an interesting process of storage and sterilization of seeds (Cardoso et al., 2004), yet during this time, and temperature variation, stored rice seeds may lose physiological quality (Marini et al., 2012). However, we previously demonstrated that rice seeds can be stored at low-temperature without losing physiological quality (Aguiar et al., 2012; Aguiar et al., 2015). Besides that, low-temperature technology has proven effectiveness in reducing the microbial population on the food surface not permitting the invasion by storage fungi, reduce the potential for attack by pathogenic microorganisms, and minimizing the loss of quality (Zuchi and Bevilaqua, 2012).

Once seed storage at elevated-temperature can lead to deterioration despite sterilization, and there is a clear need for studies aimed at establishing suitable storage conditions for rice seeds, here we evaluate the effect of low-temperature storage on the sanitary quality of rice seeds, testing different temperatures of storage and if occurs some seedto-seedling transmission.

\section{MATERIAL AND METHODS}

Plant material and seed treatments. Seeds used in this study, cultivars IRGA 423 and 424 (Irga ®), were obtained from the rice seed agro-industries from Formoso do Araguaia and Lagoa da Confusão, in the state of Tocantins - Brazil. Collected seeds were placed in a forced airflow dryer (BKIA, Carlos Becker ${ }^{\circledR}$ ) until reaching $11 \%$ of humidity. The cooling process of seeds was realized in two chambers with temperature control $\left(8\right.$ and $\left.-50^{\circ} \mathrm{C}\right)$ and a capacity of 20L. Seeds were then packed $(1.5 \mathrm{~kg})$ in sealed chambers with a volumetric capacity of $2 \mathrm{~L}$ and stored at $8 \pm 1^{\circ} \mathrm{C}$ or $-50 \pm 1^{\circ} \mathrm{C}$. The controls were kept in a paper bag $(2 \mathrm{~kg})$ at room temperature (uncontrolled conditions) with an average temperature of around $25 \pm 10^{\circ} \mathrm{C}$.

\section{Microbiological analysis and fungal} identification. To analyze the effect of lowtemperate storage on rice seeds' protection against fungal contaminations, the samples were transferred to sterile stomacher bags containing 50mL Butterfield's Phosphate Buffer after each 
storage time. The bags were kneaded for $3 \mathrm{~min}$ to obtain a homogenized spore solution. Serial dilutions were operated, and $0.5 \mathrm{~mL}$ of solution was spread on each plate with Dichloran Rose-Bengal Chloramphenicol medium. After 3 days of culturing at $30^{\circ} \mathrm{C}$, the colonies were labelled. Two replicate in triplicate were performed for each sample, and the mean of six replicates \pm standard deviation was reported. The initial spore population of untreated samples was $1.3 \times 10^{7} \mathrm{CFU} \mathrm{g}^{-1}$. The fungal identity was confirmed based on colony morphology and spore characteristics, according to Kimati et al. (1997). Single spore cultures of these fungus strains were maintained on Potato Dextrose Agar medium at $27^{\circ} \mathrm{C}$. Inoculum was prepared by using the conidia of two-week-old cultures of the fungi. The conidia were removed from the medium's surface_by flooding with sterile distilled water and gentle rubbing with a sterilized glass rod. The suspensions were filtered through cotton wool removing mycelial fragments and adjusted to $10^{5}$ conidia $\mathrm{mL}^{-1}$. Following this, all conidial and spore suspensions were used for inoculation in PDA culture medium. The results were expressed in the percentage of incidence of each fungus.

\section{Pathogen transmission via seed-to-seedling} test. Seed-to-seedling pathogen transmission analyses were done as described by Lucca Filho (1991), using seeds stored for 90 days. One-hundred seeds of each treatment were sown in sterilized recipients containing 10\% bacteriological agar substrate and sterile water. Inoculum was prepared by using the conidia of twoweek-old cultures of the fungi. The conidia were dislodged from the medium's surface_by flooding with sterile distilled water and gentle rubbing with a sterile glass rod. The suspensions were filtered through cotton wool removing mycelial fragments and adjusted to $10^{5}$ conidia $\mathrm{mL}^{-1}$. The percentage of transmission was calculated according to the seed-associated mycoflora's transport rate and the corresponding number of seedlings that developed disease symptoms.

Experimental design and statistical analysis. The experiment was conducted in a factorial arrangement of $3 \times 3 \times 2$, with three storage periods (1, 45 and 90 days), three temperatures $\left(25 \pm 10^{\circ} \mathrm{C}, 8^{\circ} \mathrm{C}\right.$, and $\left.-50^{\circ} \mathrm{C}\right)$, and two cultivars (IRGA 423 and 424). A completely randomized experimental design was used, with four replications (100 seeds per treatment, 25 seeds per plate), following the description in the Rules for Seed Testing - RAS (Ministério da Agricultura, Pecuária e Abastecimento, 2009). The data, obtained in percentage, were submitted to analysis of variance (ANOVA) and Tukey's test ( $p$ $\leq 0.05$ ), using statistical software R (R Core Team, 2019).

\section{RESULTS AND DISCUSSION}

In total, we found 14 fungal genera in the IRGA 423 seeds and 13 in the IRGA 424 seeds (Figure 1). The incidence of pathogenic fungi was higher for control seeds than_those stored at low temperatures (Figure 1 and Table 1). It was verified that at $-50^{\circ} \mathrm{C}, 45$ days of storage was a protection treatment, inhibiting the fungi's development with a_reduction of more than $60 \%$ of incidence average, and 90 days, the reduction was more than $85 \%$ (Table 1). Low-temperature storage massively reduces fungal infection on rice seeds, and almost all fungi were eliminated, except for Fusarium sp., which only reduced its incidence rate. The Trichoderma sp. was detected only in IRGA 423 seeds, whereas all other fungi detected were found in both cultivars (Figure 1). However, during the storage, when subjected to $-50^{\circ} \mathrm{C}$, it was eliminated from the rice seed. 


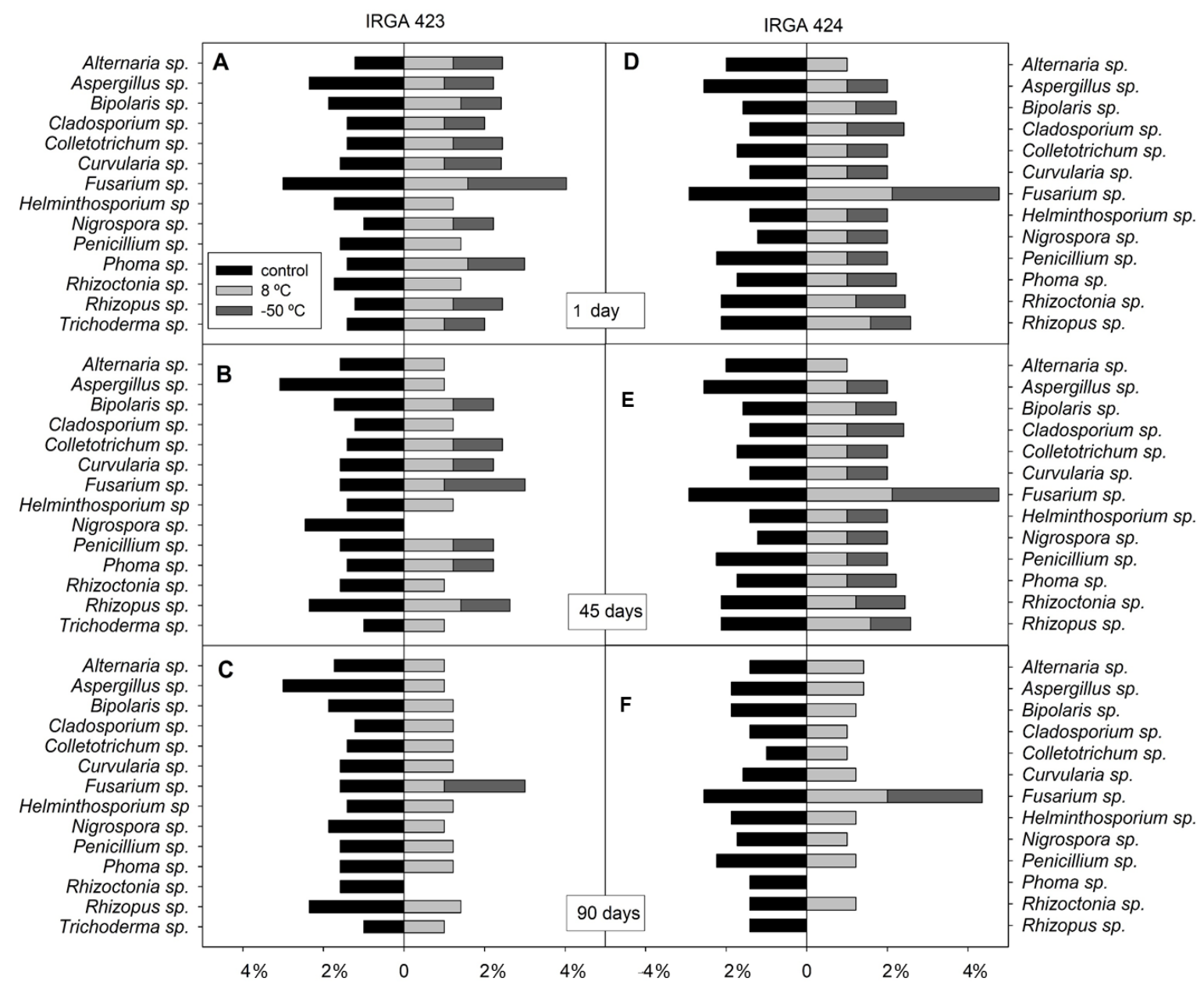

Figure 1. The microflora (percentage of infestation) of IRGA 423 (A, B, and C) and 424 (D, E, and F) rice seeds (Oryza sativa L.) after 1 (A and D), 45 (B and E), and 90 (C and F) days of storage at different temperatures.

Table 1. Average of fungi incidence rate per treatment calculated as a percentage of occurrence.

\begin{tabular}{cccccccccc}
\hline & \multicolumn{3}{c}{$\mathbf{1}$ day } & \multicolumn{4}{c}{$\mathbf{4 5}$ days } & \multicolumn{3}{c}{$\mathbf{9 0}$ days } \\
\cline { 2 - 10 } & control & $\mathbf{0 8}{ }^{\circ} \mathbf{C}$ & $\mathbf{- 5 0}{ }^{\circ} \mathbf{C}$ & control & $\mathbf{0 8}^{\circ} \mathbf{C}$ & $\mathbf{- 5 0}{ }^{\circ} \mathbf{C}$ & control & $\mathbf{0 8}{ }^{\circ} \mathbf{C}$ & $\mathbf{- 5 0}^{\circ} \mathbf{C}$ \\
\hline IRGA 423 & $1.64 \pm 0.14$ & $1.25 \pm 0.06$ & $1.01 \pm 0.18$ & $1.71 \pm 0.15$ & $1.07 \pm 0.09$ & $0.60 \pm 0.18$ & $1.70 \pm 0.14$ & $1.07 \pm 0.09$ & $0.14 \pm 0.15$ \\
IRGA 424 & $1.88 \pm 0.14$ & $1.17 \pm 0.10$ & $1.12 \pm 0.16$ & $1.69 \pm 0.11$ & $1.13 \pm 0.12$ & $0.64 \pm 0.20$ & $1.67 \pm 0.11$ & $1.07 \pm 0.15$ & $0.18 \pm 0.18$ \\
\hline
\end{tabular}

In our seed-to-seedlings transmission analyses, only Bipolaris sp. was observed. For IRGA 423, Bipolaris sp. was detected in $6 \%$ of the control seedlings but only $1 \%$ of the $8^{\circ} \mathrm{C}$ stored seedlings
(Figure 2). For IRGA 424, Bipolaris sp. was detected in $4 \%$ of the control seedlings and $1.5 \%$ of those stored at $8^{\circ} \mathrm{C}$. No pathogen transmission was detected in the $-50^{\circ} \mathrm{C}$ treatment groups (Figure 2). 


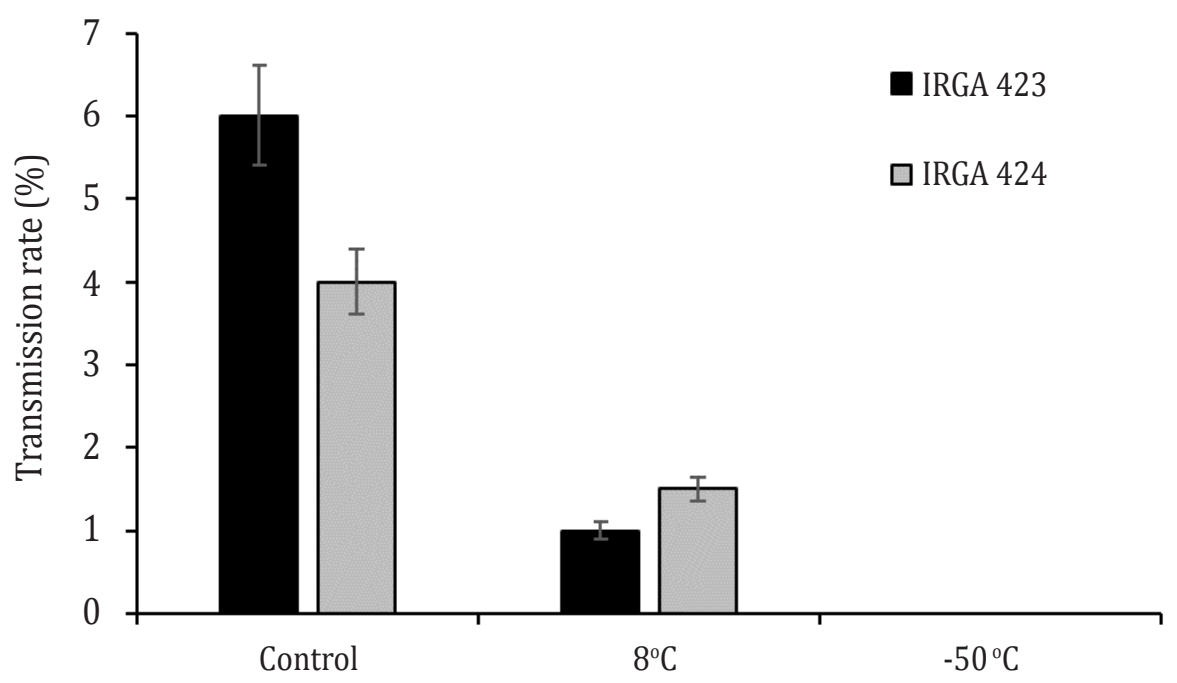

Figure 2. The effect of storage temperatures on fungal seed-to-seedling transmission for rice (Oryza sativa L.) IRGA 423 and 424 seeds after 90days of storage.

For rice seeds, temperatures above $26^{\circ} \mathrm{C}$ are considered harmful to seed quality due to gradual biochemical or physiological changes (Marini et al., 2012). Medina et al. (2009) reported poor germination and viability for triticale seeds stored under uncontrolled conditions and an increasing level of storage fungi, mainly Penicillium spp. Our findings are in line with those of Tanaka et al. (2001) that evaluated the incidence of fungi associated with corn seeds during 12 months of storage, comparing cold room $\left(14^{\circ} \mathrm{C}\right)$ storage against an uncontrolled environment. Compared to the cold chamber, , the authors observed a higher frequency of the fungi Alternaria alternata, Bipolaris maydis, Cephalosporium acremonium, Cladosporium herbarum, and Rhizoctonia solani under the uncontrolled environment; in addition, Rhizopus spp. and Trichoderma spp. Aspergillus spp. and Penicillium spp. were also more prevalent under uncontrolled conditions.

Seed-associated fungi often damage plants during their initial development, causing them to wilt or die (Malavolta et al., 2002; Maciel et al., 2012).
According to Rey et al. (2009) and Maciel et al. (2012), seeds can serve as an inoculum source for the aerial part of seedlings. Therefore, seeds are considered as means of dissemination that might introduce pathogens into pathogen-free areas or accumulate them in already infested areas through consecutive plantings of infected seeds. Improved sanitary conditions can help reducing seed-to-seedlings pathogen transmission (Maciel et al., 2012).

In the present study, although at $8^{\circ} \mathrm{C}$ storage temperature was able reducing the transmission of Bipolaris sp. to seedlings, the fungus was not eliminated. Control of temperature of storage is an important factor for conservation of seeds in tropical regions, directly affecting the biochemical and physiological processes in rice seeds and based on our data here demonstrated and previously reported (Aguiar et al., 2012), we recommend that rice seeds be stored low-temperature, preferably at $-50^{\circ} \mathrm{C}$. Obviously, any methodologies that require a large temperature change will need a great energy cost. So, this treatment could not be 
done anywhere. Another pertinent thing is that we believe that the germination rate is maintained in these conditions however further experiments are necessary.

\section{CONCLUSIONS}

Low-temperature storage massively reduces fungal association with rice seeds.

All fungi were eliminated, except for Aspergillus sp. that reported a decrease in its incidence rate.

The Trichoderma sp. was detected only in IRGA 423 seeds, whereas all other fungi detected were found in both cultivars.

In our seed-to-seedlings transmission analyses, only Bipolaris sp. was observed in both cultivars at $8^{\circ} \mathrm{C}$, while $-50^{\circ} \mathrm{C}$ was not detected.

Based on our data, we recommend that rice seeds be stored low-temperature preferably at $-50^{\circ} \mathrm{C}$.

Conflict of interest: The authors declare that there is no conflict of interest.

\section{BIBLIOGRAPHIC REFERENCES}

Adeyeye, S.A.0. (2016). Fungal mycotoxins in foods: a review. Cogent Food \& Agriculture. 2(1). doi: https:// doi.org/10.1080/23311932.2016.1213127

Aguiar, R. W. S.; Rocha D.; Ootani M.A.; Fidelis R.R.; Peluzio J.N. (2012). Efeito do dióxido de carbono, temperatura e armazenamento sobre sementes de soja e micoflora associada. Revista Ciência Agronômica (UFC. Impresso). 43:554560. doi: https://doi.org/10.1590/S180666902012000300019

Aguiar, R. W .S.; Brito, D. R.; Lopes, M. M.; Santos, G. R.; Sousa, C. M.; Silva, E. M. M.; Didonet, J. (2015). Physiological and enzymatic changes in rice seeds stored at low temperatures. African Journal of Biotechnology. 14(31): 2434-2441. doi: https://doi. org/10.5897/AJB2015.14568
Ministério da Agricultura, Pecuária e Abastecimento. (2009). Regras para análise de sementes. Brasília: Ministério da Agricultura, Pecuária e Abastecimento. Secretaria de Defesa Agropecuária. 399p.

Cardoso, P. C.; Baudet, L.; Peske, S. T.; Lucca Fillho, 0.A. (2004). Armazenamento em sistema a frio de sementes de soja tratadas com fungicida. Revista Brasileira de Sementes. 26(1): 15-23. doi: https:// doi.org/10.1590/S0101-31222004000100003

FAOSTAT - Food and Agriculture Organization of the United Nations. (2019). Statistical Yearbook. Rome, Italy: FAOSTAT.

Godfray, H. C. J.; Beddington, J. R.; Crute, I. R.; Haddad, L.; Lawrence, D.; Muir, J. F.; Pretty, J.; Robinson, S.; Thomas, S. M.; Toulmin, C. (2010). Food security: the challenge of feeding 9 billion people. Science. 327: 812-818. doi: https://doi.org/10.1126/ science.1185383

Khamsen, N.; Onwimol, D.; Teerakawanich, N.; Dechanupaprittha, S.; Kanokbannakorn, W.; Hongesombut, K.; Srisonphan, S. (2016). Rice (Oryza sativa L.) seed sterilization and germination enhancement via atmospheric hybrid nonthermal discharge plasma. ACS Applied Materials \& Interfaces. 8: 19268-19275. doi: https://doi.org/10.1021/ acsami.6b04555

Kimati, H.; Amorim, L.; Bergamin Filho, A.; Camargo, L.E.A.; Rezende, J.A.M. (1997). Manual de Fitopatologia: Doenças das Plantas Cultivadas. Vol. 2. São Paulo, Brazil: Editora Agronomica Ceres.

Lucca Filho, 0.A. (1991). Metodologia dos testes de sanidade de sementes. In: Menten, J.O.M. (Ed.). Patógenos em sementes: detecção, danos e controle químico. p. 276-298. Piracicaba: ESALQ.

Maciel, C. G.; Ferrera, T. S.; Bovolini, M. P.; Gonzatto, R.; Muniz, M.F.B.; Buriol, G.A. (2012). Transmissão de fungos via semente e patogenicidade de Pestalotiopsis sp. em mudas de Schinus terebinthifolius Raddi. Semina: Ciências Agrárias. 33(1): 2767-2774. doi: https://doi. org/10.5433/1679-0359.2012v33Supl1p2767

Malavaolta, V. M. A.; Parisi, J. J. D.; Takada, H. M.; Parisi, M. C. M. (2002). Efeito de diferentes níveis de incidência de Bipolaris oryzae em sementes de arroz sobre aspectos fisiológicos, transmissão do patógeno às plântulas e produção. Summa Phytopathologica. 28(4):337-341. 
Marini, P.; Moraes, C. L.; Marini, N.; Moraes, D. M.; Amarante, L. (2012). Alterações fisiológicas e bioquímicas em sementes de arroz submetidas ao estresse térmico. Revista Ciência Agronômica. 43(4):722-730. doi: https://doi.org/10.1590/ S1806-66902012000400014

Medina, P. F.; Tanaka, M.A.S.; Parisi, J. J. D. (2009) Sobrevivência de fungos associados ao potencial fisiológico de sementes de triticale (X. triticosecale Wittmack) durante o armazenamento. Revista Brasileira de Sementes. 31(4):17-26. doi: https:// doi.org/10.1590/S0101-31222009000400002

R Core Team. (2019). R: A language and environment for statistical computing. Recovered from https:// www.R-project.org/

Rey, M. S.; Lima, N.B.; Santos, J.; Pierobom, C. R. (2009). Transmissão semente-plântula de Colletotrichum lindemuthinum em feijão (Phaseolus vulgaris L). Arquivos do Instituto Biológico. 76(3):465-470.

Tanaka, M. A. S.; Maeda, J. A.; Plazas, I. H. A. Z. (2001). Microflora fúngica de sementes de milho em ambientes de armazenamento. Scientia Agricola. 58(3):501-508. doi: https://doi.org/10.1590/ S0103-90162001000300011

Zuchi, J.; Bevilaqua, G. A. P. (2012). Qualidade fisiológica de sementes de arroz armazenadas em diferentes embalagens e temperaturas. Recovered from https://www.embrapa.br/busca-de-publicacoes/-/ publicacao/952737/qualidade-fisiologica-desementes-de-arroz-armazenadas-em-diferentesembalagens-e-temperaturas 